$\xi=-1$

\title{
Arduino Uno-based water turbidity meter using LDR and LED sensors
}

\author{
A. P. U. Siahaan ${ }^{1 *}$, Nogar Silitonga ${ }^{2}$, Muhammad Iqbal ${ }^{1}$, Solly Aryza ${ }^{\text {, }}$ Wirda Fitriani ${ }^{1}$, \\ Zuhri Ramadhan ${ }^{1}$, Zuraidah Tharo ${ }^{1}$, Rusiadi ${ }^{3}$, Rahmad Hidayat ${ }^{3}$, H. A. Hasibuan ${ }^{3}$, \\ M. D. T. P. Nasution ${ }^{3}$, Ali Ikhwan ${ }^{4}$, Zulfi Azhar ${ }^{5}$, Mhd. Irwan Dwitama Harahap ${ }^{6}$ \\ ${ }^{1}$ Faculty of Science and Technology, Universitas Pembangunan Panca Budi, Medan, Indonesia \\ ${ }^{2}$ Faculty of Computer Science, Universitas Methodist Indonesia, Medan, Indonesia \\ ${ }^{3}$ Faculty of Social Science, Universitas Pembangunan Panca Budi, Medan, Indonesia \\ ${ }^{4}$ Faculty of Science and Technology, Universities Islam Negeri Sumatera Utara, Medan, Indonesia \\ ${ }^{5}$ Department of Information System, STMIK Royal Kisaran, Kisaran, Indonesia \\ ${ }^{6}$ Degree Student of Faculty of Science and Technology, Universitas Pembangunan Panca Budi, Medan, Indonesia \\ *Corresponding author E-mail: andiesiahaan@gmail.com
}

\begin{abstract}
Arduino Uno water turbidity gauge has been successfully designed and manufactured. This tool is made using LDR as sensor and led as a light source to measure the water turbidity value and Arduino Uno for data processing. The existence of this tool is already familiar and comfortable to find. However, the price is relatively higher to make this tool is only owned by certain circles only. Nephelometric Method is a method of measuring the turbidity of water by passing a light source on water so that the intensity of light reflected by the substances causing turbidity can be known. With the use of led as a light source and photodiode as a light detector, and combined with processing using Arduino Uno then the voltage obtained from the LDR sensor in the form of analog data is processed into digital data and can be displayed in the LCD.
\end{abstract}

Keywords: Arduino Uno; Turbidity; Water Clarity.

\section{Introduction}

An electronic device inevitably requires a power source, and this applies to the turbidity test equipment [1] [2]. Without electricity, the test equipment cannot works properly. It is an information retrieval tool to get important information. [3]-[11] [12]-[15]. A valuable information is hiding on this tool and must be extracted [16] [17]. Turbidimeter is a tool used as a standard test device serves to determine the level of turbidity of water [18]. Test equipment sold in stores is relatively expensive to make this tool is only owned by certain parties. To test whether the water we consume has a good quality should be done in the laboratory testing of drinking water. Not everyone has the time and cost to do a test to find out water quality, especially drinking water.

The study attempts to make a simple drinking water test kit. This tool is made by using a microcontroller [19]-[21]. The breakthrough in question is a tool with a dynamic form based Arduino Uno in which has planted the program to determine how much value of turbidity of water in a glass container. A program designed on a microcontroller must have high security and accuracy [22]-[28] Every person and health worker can easily see the value of turbidity of water in a container and with a simple display, and a good data process makes all walks of life can use this tool.

The author will create a tool to measure the level of turbidity of water. This system consists of Arduino microcontroller module as a data processor and Analog Digital Converter (ADC) [29]-[34] as an analog to digital converter signal because Light Emitting Diode (LED) transcribes analog data. This tool is used as a system that can detect water turbidity, the output of the tool is displayed on an LCD. Once the tool is packed, it is expected to help the related parties to determine the quality of water so that water productivity is increasing and feasible to consume.

\section{Theories}

\subsection{Nephelometric turbidity unit (NTU)}

Water is cloudy when the it contains many particles of suspended material giving it a brownish color. The ingredients that cause turbidity include sludge, well-defined organic materials, and other suspended particles. A nephelometer is a tool for measuring turbidity that gives results in units of Nephelometric Turbidity Unit (NTU) [35]-[37] it is the standard unit for measuring turbidity. In nephelometry and turbidimetry, light sources are projected through liquid samples stored in transparent sample containers. Generally, nephelometry uses light sources that have relatively short wavelengths between 500 to $800 \mathrm{~nm}$ and are effectively used to detect microscopic particles. Whereas, turbidimetry generally uses light sources that have longer wavelengths between 800 and $1100 \mathrm{~nm}$ and are effectively used to detect particles of larger size. If a beam of light is passed through a cloudy sample, its intensity is reduced by scattering, and the amount of light scattered depends on the concentration and distribution of the particle size. In nephelometry, the scattered light intensity is measured while in the turbidimetry, the intensity of the light transmitted through the sample is measured. 


\subsection{Arduino uno}

Arduino Uno is one of a series that contains microcontroller based on ATmega28 [38]. This tool is the development of an old microcontroller that has been refined with various features needed to support the microcontroller to work [39]. It also has a USB connection to do programming on the microcontroller. After the tool is programmed by connecting the USB cable to PC, Arduino Uno is ready to work. Arduino Uno has 14 digital input/output pins, six analog inputs, a $16 \mathrm{MHz}$ ceramic resonator, USB connection, input power plug, ICSP header, and a reset button [40]. Arduino Uno R3 is the latest and last series of Arduino USB series. The following picture is an Arduino Uno R3.

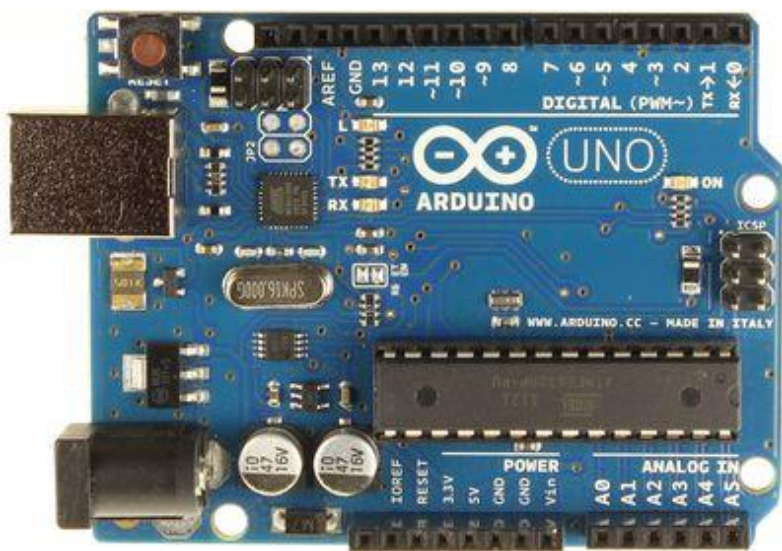

Fig. 1: Arduino Uno R3.

Arduino Uno Specification:

- ATmega328 Microcontroller

- Power Supply 5V

- Input resistance (recommendation) 7-12V

- Input resistance (limit) 6-20V

- Pin I / O Digital 14 (with 6 PWM output)

- Analog Input Pin 6

- DC current per Pin I / O 40 mA

- DC current per Pin I / O for PIN 3.3V $50 \mathrm{~mA}$

- Flash Memory $32 \mathrm{~KB}$ (ATmega328) where $0.5 \mathrm{~KB}$ is used by bootloader

- $\quad$ SRAM 2 KB (ATmega328)

- $1 \mathrm{~KB}$ EEPROM (ATmega328)

- $16 \mathrm{MHz}$ Clock Speed

\section{Methodology}

\subsection{Series of LDR and LED sensors}

Arduino Uno has 14 digital pins and six analog pins that can be used as input and output. In this circuit, the LDR sensor is connected to an Arduino analog pin. In the design of this tool LED is used as a light transmitter to be received by the color sensor. LED is connected to digital pin seven on Arduino. The sensor circuit connected to Arduino can be seen in the following picture.

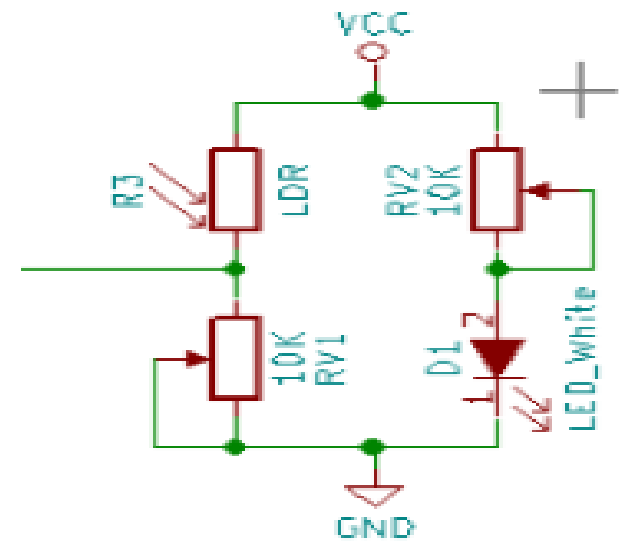

Fig. 2: LDR and LED Sensors Series.

\subsection{Design of printed circuit board}

Design of Printed Circuit Board (PCB) on the manufacture of the water turbidity detection system using Kicad to design the electronic circuit. This software facilitates the design scheme for electronic circuits and converts it into PCB design. Printed Circuit Board (PCB) is a circuit board made of ebonite (Pertinax) or glass fiber where one side of the surface is coated with thin copper. Based on the PCB arrangement is divided into three types, the first PCB Single Layer is a plain PCB that only has one layer of copper on one side. Double Layer PCB is a plain PCB that has two layers of copper on both sides, and PCB Matrix Strip Board is a PCB that has one side of copper and has holes with a regular size of 0.8 to $1 \mathrm{~mm}$. With the right design will get layout PCB path is neat and easy to use. The width and distance between paths should also be estimated to avoid errors or short links due to too tight and narrow paths. The design of PCB layout can be seen in the following picture.

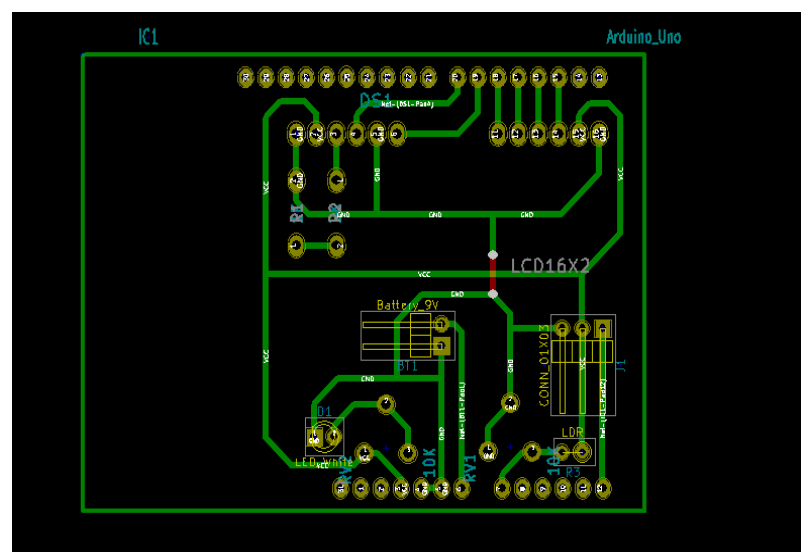

Fig. 3: PCB Design.

The component layout is the arrangement of the electronic components of the schematic diagram drawing to be mounted on the PCB surface in contrast to the PCB path. The arrangement of the electronic components must correspond to the PCB path. Each component to be installed has a size to correspond to the PCB path. Each component to be installed has the proper size and sufficient space on the PCB surface.

\subsection{LCD circuit}

The design of the LCD circuit using pin 15 to pin 20 on Arduino where on the LCD is also coupled two resistors as a controller to set the light on the LED light and setting the LDR sensor manually. The following picture is the LCD circuit 


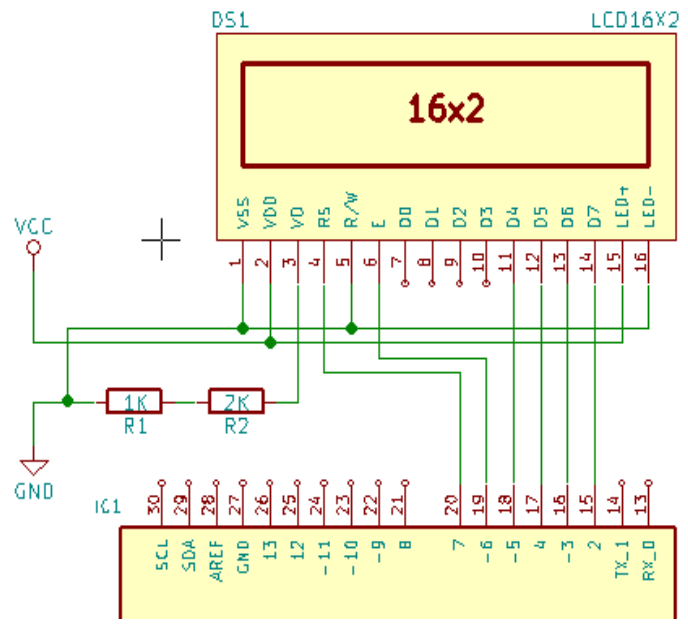

Fig. 4: LCD circuit.

\subsection{Regulator circuit}

In this design, the regulator serves to lower the incoming voltage from the battery to the Arduino into 5 volts. It is connected to the digital pin 6 as shown in the following figure.

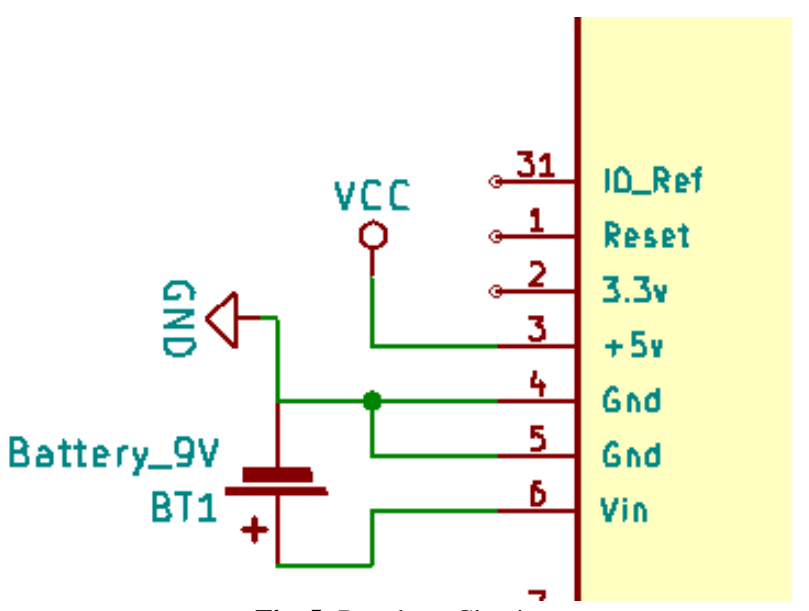

Fig. 5: Regulator Circuit

\subsection{Indicator light}

The design of the tool is made in such a way as to facilitate the user in its application. The authors have designed three pieces indicator lights as a marker of the value of turbidity of water. Description of the indicator light itself can be seen in the following table.

Table 1: Indicator Description

\begin{tabular}{ll} 
& Table 1: Indicator Description \\
\hline NTU Value & Status \\
\hline $0-5$ & Green light (Clear) \\
$6-99$ & Yellow light (Turbid) \\
$100-500$ & Red light (Dark) \\
\hline
\end{tabular}

\subsection{Overall tool series}

The whole circuit has been connected with each pin on Arduino Uno. The various tools and materials used are Arduino Uno, PCB resistor, potentiometer, 16x2 LCD, LDR (Light Dependence Resistance), LED, USB port, 9V Battery Socket and 9v Battery. Overall can be seen circuit system based on Functions and their goals on each pin Arduino Uno. The whole set of Tools can be seen in the following figure.

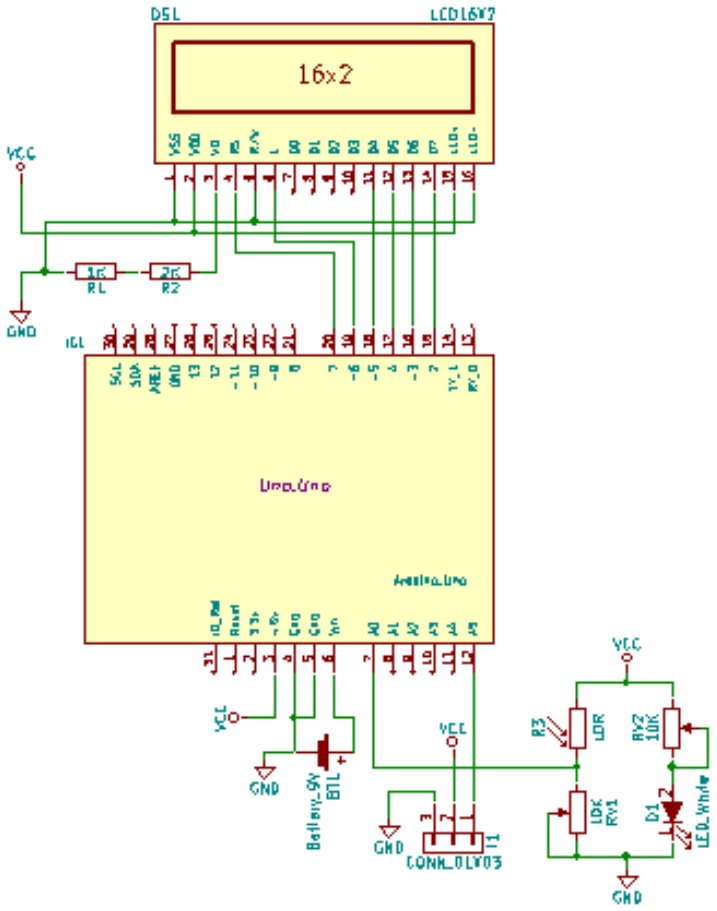

Fig. 6: Overall Circuit.

\section{Result and discussion}

\subsection{Test result}

The tests were performed using a completed turbidity measuring device to determine the turbidity value by using multiple experimental samples. This test is conducted to determine the difference of turbidity level of water read by the sensors contained in the tool. The sample used is the ink water with the ratio of the number of droplets in 5 experiments to determine the amount of turbidity value. Test results using ink water can be seen in the following figure.

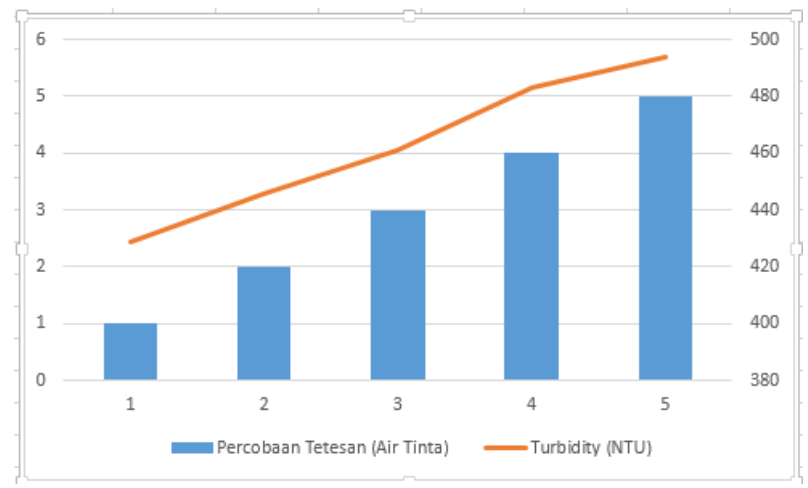

Fig. 7: Test Result

The following table is the NTU value comparison result based on the five tests of ink water.

Table 2: NTU Comparison

\begin{tabular}{ll}
\hline Test Number & NTU Value \\
\hline 1 & 429 \\
2 & 446 \\
3 & 461 \\
4 & 483 \\
5 & 494 \\
\hline
\end{tabular}

\subsection{Determination of NTU value}

In determining the value of turbidity of water based on the results of previous sample testing, it is determined the value of NTU 
using the formula $\mathrm{y}=-111.25 \mathrm{x}+506.67$ where -111.25 and 506.67 is the determination value determined based on NTU assumption of aqua water samples with assuming the value of $\mathrm{NTU}=0$ and from the most concentrated ink water sample assuming the value of NTU $=500$ whereas $\mathrm{x}$ is the voltage value.

Table 3: ADC to NTU Scale

\begin{tabular}{ll}
\hline ADC Value & NTU Value \\
\hline 4.55 & 0.5 \\
0.06 & 500 \\
\hline
\end{tabular}

The result of the sample test in aqua water produces the voltage value is 4.55 Volt and based on the sample test result on the real ink water; it is obtained the voltage value of 0.06 volts.

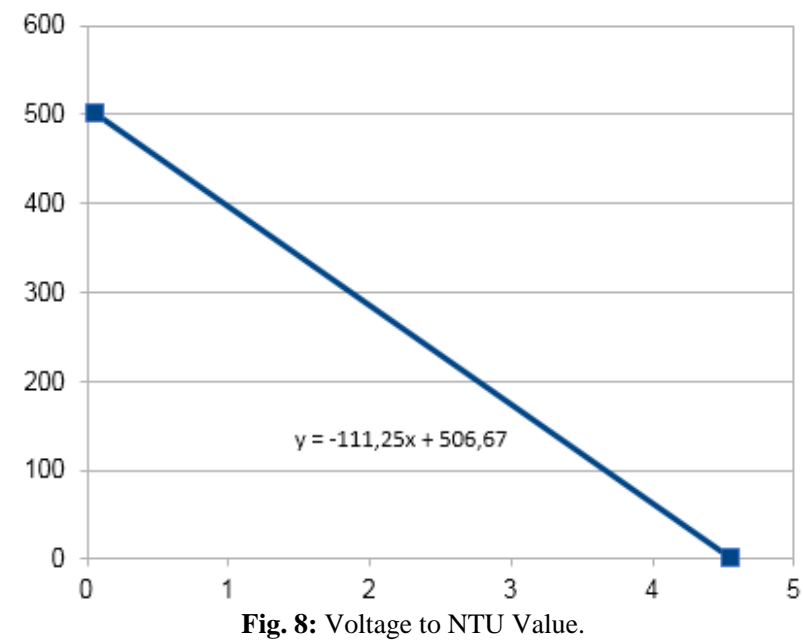

Figure 8 is an NTU value of 0 with a voltage value of 4.55 volts for a sample of clean water and obtained a value of NTU of 500 with a voltage value of 0.06 volts for dark water.

\section{Conclusion}

Based on the results of research and manufacture of water turbidity test, it can be concluded that the results of water sample test shows that the tool has functioned well and able to provide turbidity value of water by using different samples. In the test, clear water produces a voltage value of 4.55 volts with an NTU value of close to 0 while the test results of cloudy and dark water samples yield a voltage value of 0.06 volts with an NTU value close to 500. The equation for obtaining the value of NTU is $y=-$ $111.25 \mathrm{x}+506.67$. This tool can be used to determine the water turbidity level.

\section{References}

[1] S. Aryza, M. Irwanto, Z. Lubis, A. P. U. Siahaan, R. Rahim, and M Furqan, "A Novelty Design of Minimization of Electrical Losses in A Vector Controlled Induction Machine Drive," in IOP Conference Series: Materials Science and Engineering, 2018, vol. 300, no. 1. https://doi.org/10.1088/1757-899X/300/1/0120670.

[2] A. P. U. Siahaan et al., "Combination of Levenshtein Distance and Rabin-Karp to Improve the Accuracy of Document Equivalence Level," Int. J. Eng. Technol., vol. 7, no. 2.27, pp. 17-21, 2018.

[3] A. P. U. Siahaan, "The Analysis of Average Waiting Time in Managing Concurrent Process."

[4] L. Marlina, Muslim, and A. P. U. Siahaan, "Data Mining Classification Comparison (Naïve Bayes and C4.5 Algorithms)," Inte rnational J. Eng. Trends Technol., vol. 38, no. 7, pp. 380-383, 2016. https://doi.org/10.14445/22315381/lJETT-V38P268.

[5] Z. Ramadhan and A. P. U. Siahaan, "Dining Philosophers Theory and Concept in Operating System Scheduling," IOSR J. Comput. Eng., vol. 18, no. 6, pp. 45-50, 2016.

[6] D. Kurnia, H. Dafitri, and A. P. U. Siahaan, "RSA 32-bit Implementation Technique," Int. J. Recent Trends Eng. Res., vol. 3,

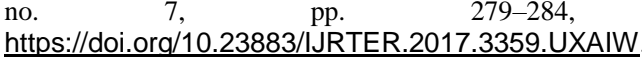

2017.

7] S. Hartanto, M. Furqan, A. P U. Siahaan, and W. Fitriani, "Haversine Method in Looking for the Nearest Masjid," Int. J. Recent Trends Eng. Res., vol. 3, no. 8, pp. 187-195, Aug. 2017. https://doi.org/10.23883/IJRTER.2017.3402.PD61H

[8] H. M. Ritonga, A. P. U. Siahaan, and Suginam, "Marketing Strategy through Markov Optimization to Predict Sales on Specific Periods," Int. J. Innov. Res. Multidiscip. F., vol. 3, no. 8, pp. 184 190, 2017.

[9] I. Sumartono, A. P. U. Siahaan, and Arpan, "Base64 Character Encoding and Decoding Modeling," Int. J. Recent Trends Eng. Res., vol. 2, no. 12, pp. 63-68, 2016.

[10] W. Fitriani, R. Rahim, B. Oktaviana, and A. P. U. Siahaan, "Vernam Encypted Text in End of File Hiding Steganography Technique," Int. J. Recent Trends Eng. Res., vol. 3, no. 7, pp. 214219 , Jul. https://doi.org/10.23883/IJRTER.2017.3351.6ON8H.

[11] W. Fitriani and A. P. U. Siahaan, "Comparison Between WEKA and Salford System in Data Mining Software," Int. J. Mob. Comput. Appl., vol. 3, no. 4, pp. 1-4, 2016.

[12] Mesran, K. Tampubolon, R. D. Sianturi, F. T. Waruwu, and A. P. U. Siahaan, "Determination of Education Scholarship Recipients Using Preference Selection Index," Int. J. Sci. Res. Sci. Technol., vol. 3, no. 6, pp. 230-234, 2017.

[13] M. Iqbal, M. A. S. Pane, and A. P. U. Siahaan, "SMS Encryption Using One-Time Pad Cipher," IOSR J. Comput. Eng., vol. 18, no. 6, pp. 54-58, 2016.

[14] B. Oktaviana and A. P. U. Siahaan, "Three-Pass Protocol Implementation on Caesar Cipher in Classic Cryptography," IOSR J. Comput. Eng., vol. 18, no. 4, pp. 26-29, 2016. https://doi.org/10.9790/0661-1804032629.

[15] A. P. U. Siahaan, "Comparison Analysis of CPU Scheduling: FCFS, SJF and Round Robin," Int. J. Eng. Dev. Res., vol. 4, no. 3, pp. 124-131, 2016.

[16] A. P. U. Siahaan and R. Rahim, "Dynamic Key Matrix of Hill Cipher Using Genetic Algorithm," Int. J. Secur. Its Appl., vol. 10, no. 8, pp. 173-180, Aug. 2016.

[17] A. P. U. Siahaan, "Adler-32 Integrity Validation in 24bit Color Image."

[18] S. Bin Ibrahim, "Turbidity Measurement Using An Optical Tomography System,” Int. J. Sci. Eng., vol. 5, no. 2, Oct. 2013.

[19] Prerana, M. R. Shenoy, B. P. Pal, and B. D. Gupta, "Design, Analysis, and Realization of a Turbidity Sensor Based on Collection of Scattered Light by a Fiber-Optic Probe," IEEE Sens. J., vol. 12, no. 1, pp. 44-50, Jan. 2012. https://doi.org/10.1109/JSEN.2011.2128306.

[20] J. Park, K. Park, K. Han, and K. Park, "Design and implementation of 2 channels turbidity sensor modules," in 2013 10th International Conference on Ubiquitous Robots and Ambient Intelligence (URAI), 2013, pp. 447-450. https://doi.org/10.1109/URAI.2013.6677307.

[21] S. C. Liew, B. Saengtuksin, and L. K. Kwoh, "Monitoring turbidity and suspended sediment concentration of coastal and inland waters using satellite data," in 2009 IEEE International Geoscience and Remote Sensing Symposium, 2009, p. II-837-II-839. https://doi.org/10.1109/IGARSS.2009.5418225

[22] A. Lubis and A. P. U. Siahaan, "Network Forensic Application in General Cases," IOSR J. Comput. Eng., vol. 18, no. 6, pp. 41-44, 2016.

[23] A. P. U. Siahaan, "Genetic Algorithm in Hill Cipher Encryption," Am. Int. J. Res. Sci. Technol. Eng. Math., vol. 15, no. 1, pp. 84-89, 2016.

[24] A. P. U. Siahaan, "Rail Fence Cryptography in Securing Information."

[25] A. P. U. Siahaan, "Huffman Text Compression Technique."

[26] R. D. Sari, Supiyandi, A. P. U. Siahaan, M. Muttaqin, and R. B. Ginting, "A Review of IP and MAC Address Filtering in Wireless Network Security," Int. J. Sci. Res. Sci. Technol., vol. 3, no. 6, pp. 470-473, 2017

[27] A. P. U. Siahaan, "Securing Short Message ServiceUsing Vernam Cipher in Android Operating System," IOSR, Apr. 2016.

[28] A. P. U. Siahaan, "A Three-Layer Visual Hash Function Using Adler-32,” Int. J. Comput. Sci. Softw. Eng., vol. 5, no. 7, pp. 142$147,2016$.

[29] A. P. U. Siahaan, "Vernam Conjugated Manipulation of Bit-Plane Complexity Segmentation."

[30] A. P. U. Siahaan, "Adjustable Knapsack in Travelling Salesman Problem Using Genetic Process," Int. J. Sci. Technoledge, vol. 4, no. 9 , pp. $46-55,2016$ 
[31] A. P. U. Siahaan, "Penyelarasan Pada Masalah Dining Philosophers Menggunakan Algoritma Lock \& Release," Techsi, vol. 6, no. 1, 2014.

[32] A. P. U. Siahaan, "High Complexity Bit-Plane Security Enchancement in BPCS Steganography," Int. J. Comput. Appl., vol. 148, no. 3, pp. 17-22, 2016.

[33] Z. Sitorus and A. P. U. Siahaan, "Heuristic Programming in Scheduling Problem Using A* Algorithm," IOSR J. Comput. Eng., vol. 18 , no. 5, pp. 71-79, 2016.

[34] A. P. U. Siahaan, "Blum Blum Shub in Generating Key in RC4," Int. J. Sci. Technoledge, vol. 4, no. 10, pp. 1-5, 2016.

[35] T. P. Lambrou, C. C. Anastasiou, and C. G. Panayiotou, "A Nephelometric Turbidity System for Monitoring Residential Drinking Water Quality," 2010, pp. 43-55.

[36] M. Asrafuzzaman, A. N. M. Fakhruddin, and M. A. Hossain "Reduction of Turbidity of Water Using Locally Available Natural Coagulants," ISRN Microbiol., vol. 2011, pp. 1-6, 2011. https://doi.org/10.5402/2011/632189

[37] M. T. Mohd Khairi, S. Ibrahim, M. A. Md Yunus, and M. Faramarzi, "A review on the design and development of turbidimeter," Sens. Rev., vol. 35, no. 1, pp. 98-105, Jan. 2015. https://doi.org/10.1108/SR-01-2014-604.

[38] Y. A. Badamasi, "The working principle of an Arduino," in 2014 11th International Conference on Electronics, Computer and Computation (ICECCO), 2014, pp. 1-4. https://doi.org/10.1109/ICECCO.2014.6997578.

[39] Febrianto, "Apa itu Arduino Uno?," Referensi Teknologi dan Elektronika Indonesia, 2018. [Online]. Available: http://ndoware.com/apa-itu-arduino-uno.html. [Accessed: 01-Jun2018].

[40] M. A. B. Sidik et al., "Arduino-Uno Based Mobile Data Logger with GPS Feature," TELKOMNIKA (Telecommunication Comput. Electron. Control., vol. 13, no. 1, p. 250, Mar. 2015. 